\title{
EFEKTIVITAS HIDROGEN PEROKSIDA DALAM PENGENDALIAN INFEKSI EKTOPARASIT PADA IKAN LELE Clarias gariepinus
}

\author{
Septyan Andriyanto*\#, Uni Purwaningsih*), Shofihar Sinansari**), dan Yohanna Retnaning Widyastuti*) \\ *) Balai Riset Perikanan Budidaya Air Tawar dan Penyuluhan Perikanan \\ **) Balai Riset Budidaya Ikan Hias
}

(Naskah diterima: 21 April 2017; Revisi final: 22 Maret 2018; Disetujui publikasi: 22 Maret 2018)

\begin{abstract}
ABSTRAK
Penggunaan bahan kimiawi yang aman dan ramah lingkungan merupakan salah satu metode yang banyak digunakan untuk pengobatan penyakit parasitik pada budidaya ikan, meskipun masih sedikit informasi mengenai efektivitas penggunaan hidrogen peroksidauntuk pengobatan penyakit parasitik pada ikan air tawar di Indonesia. Penelitian bertujuan untuk mengetahui dosis efektif hidrogen peroksida $\left(\mathrm{H}_{2} \mathrm{O}_{2}\right)$ dan pengaruhnya terhadap infeksi ektoparasit pada ikan lele Clarias gariepinus. Perlakuan yang digunakan adalah penambahan $\mathrm{H}_{2} \mathrm{O}_{2}$ dalam media pemeliharaan dengan dosis berbeda yaitu: (A) aplikasi $\mathrm{H}_{2} \mathrm{O}_{2}$ dosis $100 \mathrm{mg} / \mathrm{L}$, (B) aplikasi $\mathrm{H}_{2} \mathrm{O}_{2}$ dosis $200 \mathrm{mg} / \mathrm{L}$, (C) aplikasi $\mathrm{H}_{2} \mathrm{O}_{2}$ dosis $300 \mathrm{mg} / \mathrm{L}$, dan (D) tanpa aplikasi $\mathrm{H}_{2} \mathrm{O}_{2}$ atau kontrol. Pemberian hidrogen peroksida dilakukan satu kali pada awal pengujian dan tiap perlakuan menggunakan tiga ulangan. Pemeriksaan sampel dilakukan setiap hari terhadap tingkat infestasi dan prevalensi ektoparasit selama enam hari pemeliharaan. Pengamatan hanya dilakukan pada parasit dewasa yang memiliki organ tubuh lengkap dan telah melewati fase telur. Fokus penelitian untuk memperoleh informasi dosis $\mathrm{H}_{2} \mathrm{O}_{2}$ yang paling efektif menekan infeksi ektoparasit selama enam hari pengujian. Hasil penelitian menunjukkan bahwa aplikasi hidrogen peroksida dosis $300 \mathrm{mg} / \mathrm{L}$ efektif menekan tingkat infestasi dan prevalensi parasit Trichodina sp., Dactylogyrus sp., dan Gyrodactylus sp., diikuti dosis 200 mg/L, 100 mg/ $\mathrm{L}$, dan terendah pada kontrol. Berdasarkan analisis statistik diperoleh nilai infestasi parasit yang berbeda nyata $(P<0,05)$ antara perlakuan aplikasi $\mathrm{H}_{2} \mathrm{O}_{2}$ dibandingkan dengan kontrol atau tanpa aplikasi $\mathrm{H}_{2} \mathrm{O}_{2}$.
\end{abstract}

KATA KUNCl: parasit; prevalensi; hidrogen peroksida

ABSTRACT: The effectivity of hydrogen peroxide application to control ectoparasite infestations on African catfish, Clarias gariepinus. By: Septyan Andriyanto, Uni Purwaningsih, Shofihar Sinansari, and Yohanna Retnaning Widyastuti

Chemical compounds that are safe and environmentally friendly has been widely used to treat parasitic diseases in fish farming. However, there is limited information on the effectiveness of the application of hydrogen peroxide to treat parasitic diseases in freshwater fish in Indonesia. The study was aimed to determine the effective dose of hydrogen peroxide $\left(\mathrm{H}_{2} \mathrm{O}_{2}\right)$ and its influence on the presence of ectoparasites on Clarias gariepinus catfish. The treatment used was the addition of $\mathrm{H}_{2} \mathrm{O}_{2}$ in the media preservation at different doses, namely: the application of $\mathrm{H}_{2} \mathrm{O}_{2}$ dose of $(\mathrm{A}) 100$ $\mathrm{mg} / \mathrm{L}$, (B) $200 \mathrm{mg} / \mathrm{L}$, (C) $300 \mathrm{mg} / \mathrm{L}$, and (D) without $\mathrm{H}_{2} \mathrm{O}_{2}$ or control. Treatment media were exposed to hydrogen peroxide once at the beginning of the test and each treatment used three replications. Infestation and ectoparasite prevalence were observed daily for six days. The observations were only performed on adult parasites that have complete organs and passed the egg stage. The study focuses on obtaining the most effective dose of $\mathrm{H}_{2} \mathrm{O}_{2}$ to suppress ectoparasite infection within six days. The results showed that the application of hydrogen peroxide of $300 \mathrm{mg} / \mathrm{L}$ was the most effective dose to suppress the infestation level and prevalence of Trichodina sp., Dactylogyrus sp., and Gyrodactylus sp., followed by $200 \mathrm{mg} / \mathrm{L}, 100 \mathrm{mg} / \mathrm{L}$, and the lowest was in control. The statistical analysis of the parasite infestation had shown a significant difference $(\mathrm{P}<0.05)$ between the treatment of $\mathrm{H}_{2} \mathrm{O}_{2}$ as compared with the control.

\section{KEYWORDS: parasites; prevalence; hydrogen peroxide}

\footnotetext{
\# Korespondensi: Balai Riset Perikanan Budidaya Air Tawar dan

Penyuluhan Perikanan. Jl. Raya Sempur No. 1, Bogor 16154,

Indonesia.

Tel.: + 622518313200

E-mail: septian08@yahoo.com
} 


\section{PENDAHULUAN}

Penyakit merupakan kendala serius dalam proses budidaya ikan. Salah satu penyakit tersebut adalah serangan parasit yang menjadi salah satu faktor predisposisi bagi infeksi organisme patogen lainnya yang lebih berbahaya (secondary infection). Beberapa spesies ektoparasit yang umumnya ditemukan menginfestasi ikan air tawar berasal dari golongan protozoa dan cacing monogenea yaitu Trichodina sp., Dactylogyrus sp., dan Gyrodactylus sp. Ketiga parasit tersebut penyebab munculnya penyakit parasitik potensial pada ikan budidaya air tawar (Lom \& Dyková, 1992; Christison et al., 2005). Jenis parasit dari golongan protozoa banyak ditemukan pada tubuh inang dikarenakan memiliki karakteristik berupa pergerakan yang cepat, wilayah serangan luas, menyerang dalam jumlah banyak, serta memiliki toleransi yang sangat tinggi terhadap suhu perairan (Kabata, 1985). Sebagian besar cacing monogenea menyerang bagian luar tubuh ikan terutama kulit dan insang, dan jarang menyerang bagian dalam tubuh ikan (William \& Jones, 1994).

Trichodina sp., Dactylogyrus sp., dan Gyrodactylus sp. umumnya ditemukan pada bagian eksternal tubuh ikan dikarenakan jenis parasit tersebut bersifat ektoparasit (Singkoh, 2012). Cacing monogenea dari genus Gyrodactylus merupakan patogen yang berpengaruh terhadap keberhasilan budidaya, serta keberadaan ikan di habitat aslinya (Rubio-Godoy et al., 2012). Beberapa genus cacing monogenea merupakan patogen utama dalam budidaya catfish (Prikrylová et al., 2012), di antara spesies parasit dari kelas monogenea yang umumnya menyerang ikan lele yaitu Dactylogyrus sp. dan Gyrodactylus sp. (Dirkesling, 2014).

Penggunaan bahan kimiawi yang aman dan ramah lingkungan merupakan salah satu metode yang banyak digunakan dalam pengobatan penyakit parasitik dan telah lama dilakukan dalam proses budidaya ikan. Namun, keterbatasan informasi terkait jenis bahan yang aman dan ramah lingkungan, dosis efektif, serta prosedur pemberian yang tepat merupakan permasalahan pada sebagian besar pembudidaya di Indonesia. Dewan negara-negara Eropa atau European Council berdasarkan Council Regulation (EEC) No. 2377/ 90 telah mengeluarkan peraturan terkait bahan-bahan kimia, serta ambang batas maksimum yang diperbolehkan untuk dipergunakan pada produk peternakan dan perikanan. Beberapa bahan kimia yang diijinkan penggunaannya untuk pencegahan dan pengobatan penyakit parasitik pada ikan di antaranya acetic acid, betadine, bithionol, chloramin-t, copper sulfate, formaldehyde, hydrogen peroxide, ivermectin, levamisol, mebendazole, niclosamid, potassium perman- ganate, praziquentel, salt, trichlorphon (Kayis et al., 2009).

Hidrogen peroksida $\left(\mathrm{H}_{2} \mathrm{O}_{2}\right)$ merupakan salah satu bahan kimia yang telah banyak dimanfaatkan untuk kepentingan industri, kesehatan maupun lingkungan. Pada kegiatan akuakultur, hidrogen peroksida digunakan untuk mengatasi infeksi jamur pada telur ikan, serta mengontrol bakteri dan parasit pada ikan budidaya. Hidrogen peroksida di alam ditemukan pada hampir seluruh permukaan air yang terpapar sinar ultraviolet dalam bentuk dissolved organic carbon (DOC). Konsentrasi $\mathrm{H}_{2} \mathrm{O}_{2}$ air tawar berkisar antara 0,001 hingga 0,109 mg/L; sedangkan air laut berkisar 0,001 sampai $0,0136 \mathrm{mg} / \mathrm{L}$. Semakin tinggi konsentrasi $\mathrm{H}_{2} \mathrm{O}_{2}$ menunjukkan semakin tingginya kandungan DOC pada permukaan air. Hidrogen peroksida memiliki sifat alami mudah larut (degradable) dalam air maupun oksigen. Proses degradasi tersebut melalui beberapa mekanisme di antaranya reduksi kimiawi dan secara enzimatis berupa dekomposisi oleh alga, zooplankton, dan bakteri heterotropik. Mikoorganime khususnya bakteri berperan paling penting dalam proses degradasi $\mathrm{H}_{2} \mathrm{O}_{2}$ dibanding mekanisme kimiawi dan biologi lainnya. Lama waktu yang diperlukan $\mathrm{H}_{2} \mathrm{O}_{2}$ untuk terdegradasi dalam air bervariasi antara beberapa menit hingga lebih dari satu minggu, tergantung dari faktor kimia, biologi, dan fisika yang memengaruhinya (Schmidt et al., 2006).

Penelitian aplikasi bahan kimiawi yang aman dan ramah lingkungan perlu dilakukan dalam rangka pengendalian penyakit parasitik potensial pada budidaya ikan air tawar. Penelitian bertujuan untuk mengetahui dosis efektif dari hidrogen peroksida, $\mathrm{H}_{2} \mathrm{O}_{2}$ dan pengaruhnya terhadap infeksi ektoparasit pada ikan lele Clarias gariepinus.

Penelitian hanya difokuskan untuk memperoleh informasi dosis efektif $\mathrm{H}_{2} \mathrm{O}_{2}$, serta data hasil inventarisasi dan identifikasi ektoparasit selama pengujian. Efektivitas waktu pemberian, uji mutu, dan keamanan hidrogen peroksida terhadap ikan dan lingkungan direncanakan menjadi tema penelitian pada tahun berikutnya. Hasil dari penelitian diharapkan dapat menjadi alternatif dalam pengendalian penyakit parasitik potensial pada budidaya ikan lele dan ikan air tawar pada umumnya.

\section{BAHAN DAN METODE}

Ikan lele dengan rerata panjang 9,77 $\pm 0,89 \mathrm{~cm}$ dan rerata bobot 7,61 $\pm 1,67 \mathrm{~g}$ digunakan sebagai ikan uji, sedangkan hidrogen peroksida yang digunakan dalam pengujian merupakan hidrogen peroksida p.a. (no. katalog. 8.22287.1000). Ikan diaklimatisasi dalam bak pemeliharaan terlebih dahulu sebelum dilakukan 
pengujian. Sebanyak 500 ekor ikan lele diaklimatisasi dalam bak fiber glass ukuran $1.000 \mathrm{~L}$ dengan volume air sebanyak $500 \mathrm{~L}$ selama empat minggu. Setiap dua minggu sekali sebanyak 12 ekor ikan uji diperiksa secara mikroskopis untuk mengetahui prevalensi ektoparasitnya sebelum diberikan perlakuan. Selama pemeliharaan ikan uji diberi pakan komersial dengan kandungan protein $28 \%$ secara ad libitum.

Proses pengujian selanjutnya dilakukan dalam 12 unit bak plastik ukuran $40 \mathrm{~L}$ (volume air $10 \mathrm{~L}$ ). Ikan lele ditempatkan dalam wadah pengujian dengan kepadatan 15 ekor/bak. Perlakuan yang diterapkan dalam pengujian adalah pemberian hidrogen peroksida dengan empat dosis berbeda, yaitu: A) $100 \mathrm{mg} / \mathrm{L}$, B) $200 \mathrm{mg} / \mathrm{L}$, C) $300 \mathrm{mg} / \mathrm{L}$, dan D) tanpa pemberian $\mathrm{H}_{2} \mathrm{O}_{2}$ sebagai kontrol. Hidrogen peroksida hanya diberikan satu kali yaitu pada awal pengujian untuk enam hari masa pemeliharaan.

Pemeriksaan parasit yang menginfestasi ikan uji dilakukan setiap hari selama enam hari periode pengujian. Parasit yang diamati merupakan parasit dewasa dengan organ tubuh lengkap dan telah melewati fase telur. Sebanyak dua ekor sampel ikan dari tiap perlakuan diperiksa setiap harinya untuk mengetahui ektoparasit yang menginfestasi. Sampel ikan dimatikan terlebih dahulu sebelum dilakukan pemeriksaan dengan cara menusuk bagian medulla oblongata menggunakan alat bedah. Bagian tubuh yang diperiksa meliputi kulit, sirip, dan insang. Pemeriksaan kulit dilakukan dengan mengerok lendir (mucus) pada permukaan tubuh ikan uji (termasuk pada bagian tubuh yang terluka) menggunakan cover glass dari arah operculum menuju ekor. Pemeriksaan sirip dilakukan dengan menggunting bagian sirip punggung atau sirip ekor, terutama yang memiliki bentuk dan penampakan yang tidak normal. Pemeriksaan insang dilakukan dengan menggunting lembaran insang (lamella) terluar bagian kanan atau kiri insang, selanjutnya sampel organ diletakkan pada kaca preparat yang telah ditetesi akuades untuk diamati secara mikroskopis.

Pengamatan ektoparasit dilakukan di bawah mikroskop cahaya pada perbesaran 4x, 10x, 20x, dan 40x. Proses identifikasi ektoparasit mengacu pada buku identifikasi parasit di antaranya Hoffman (1967), Schell (1970), Kudo (1977), serta William \& Jones (1994).

Pemeriksaan ektoparasit mengikuti prosedur pengujian di laboratorium parasitologi Instalasi Riset Pengendalian Penyakit Ikan-Balai Riset Perikanan Budidaya Air Tawar dan Penyuluhan Perikanan (IRP2IBRPBATPP) meliputi dua parameter, yaitu: 1) tingkat infestasi ektoparasit yang dihitung berdasarkan rerata jumlah individu (ind.) ektoparasit yang teramati pada tiga lapang pandang mikroskop; dan 2) prevalensi ektoparasit yang dihitung dari setiap sampel ikan uji dalam satu wadah penelitian menggunakan rumus: Prevalensi $=$ (jumlah ikan yang terserang parasit $/$ jumlah ikan yang diperiksa) x 100\%

Data tingkat infestasi parasit dianalisis secara deskriptif dan statistik menggunakan ANOVA dengan tingkat kepercayaan 95\%untuk melihat perbedaan dari masing-masing perlakuan.

\section{HASIL DAN BAHASAN}

\section{Identifikasi Parasit}

Parasit yang teridentifikasi selama penelitian terdiri atas tiga jenis ektoparasit yaitu Trichodina sp., Dactylogyrus sp., dan Gyrodactylus sp. Pengamatan sampel ikan uji selama proses aklimatimasi menunjukkan bahwa ikan-ikan uji pada minggu kedua terinfeksi parasit protozoa Trichodina sp. dengan prevalensi sebesar $87,5 \%$ Nilai prevalensi parasit monogenea Dactylogyrus sp. dan Gyrodactylus sp. yang ditemukan sebesar $62,5 \%$ Pada minggu keempat dilakukan pemeriksaan kembali dan diperoleh nilai prevalensi parasit Trichodina sp. sebesar 83,3\% parasit cacing Dactylogyrus sp. sebesar $75 \%$ dan Gyrodactylus sp. sebesar 58,3\% Berdasarkan hasil pengamatan selanjutnya dilakukan plotting ikan uji untuk penelitian pengujian dosis efektif hidrogen peroksida. Penelitian dilakukan secara bertahap dimulai dengan pengujian dosis hidrogen peroksida secara in vitro dan dilanjutkan uji in vivo.

\section{Tingkat Infestasi}

Pengamatan tingkat infestasi ektoparasit setelah aplikasi $\mathrm{H}_{2} \mathrm{O}_{2}$ dosis $300 \mathrm{mg} / \mathrm{L} \mathrm{menunjukkan} \mathrm{efektivitas}$ tertinggi pada hari ke-6 pasca perlakuan dengan tidak ditemukan adanya ektoparasit (Gambar 1). Berbeda halnya dengan perlakuan dosis 100 mg/L dan 200 mg/ $\mathrm{L}$, pada akhir penelitian masih ditemukan parasit yang menginfestasi, meskipun jumlahnya tidak sebanyak dibandingkan dengan kontrol. Infestasi ektoparasit berfluktuatif selama pengujian yang diperlihatkan dengan pola yang naik turun. Hal tersebut dikarenakan mekanisme reaksi hidrogen peroksida dalam tubuh tiap parasit memiliki waktu yang berbeda-beda, sehingga parasit yang ditemukan jumlahnya tidak sama dalam setiap pengamatan. Selain itu, siklus hidup parasit juga dapat memengaruhi tingkat infestasi parasit. Hal tersebut dimungkinkan karena efek hidrogen peroksida lebih berpengaruh pada parasit dewasa yang memiliki organ tubuh lengkap dibandingkan dengan parasit yang masih dalam fase telur. Menurut Halliwel \& Gutteridge (2015), bahwa hidrogen peroksida memiliki kemampuan menembus 


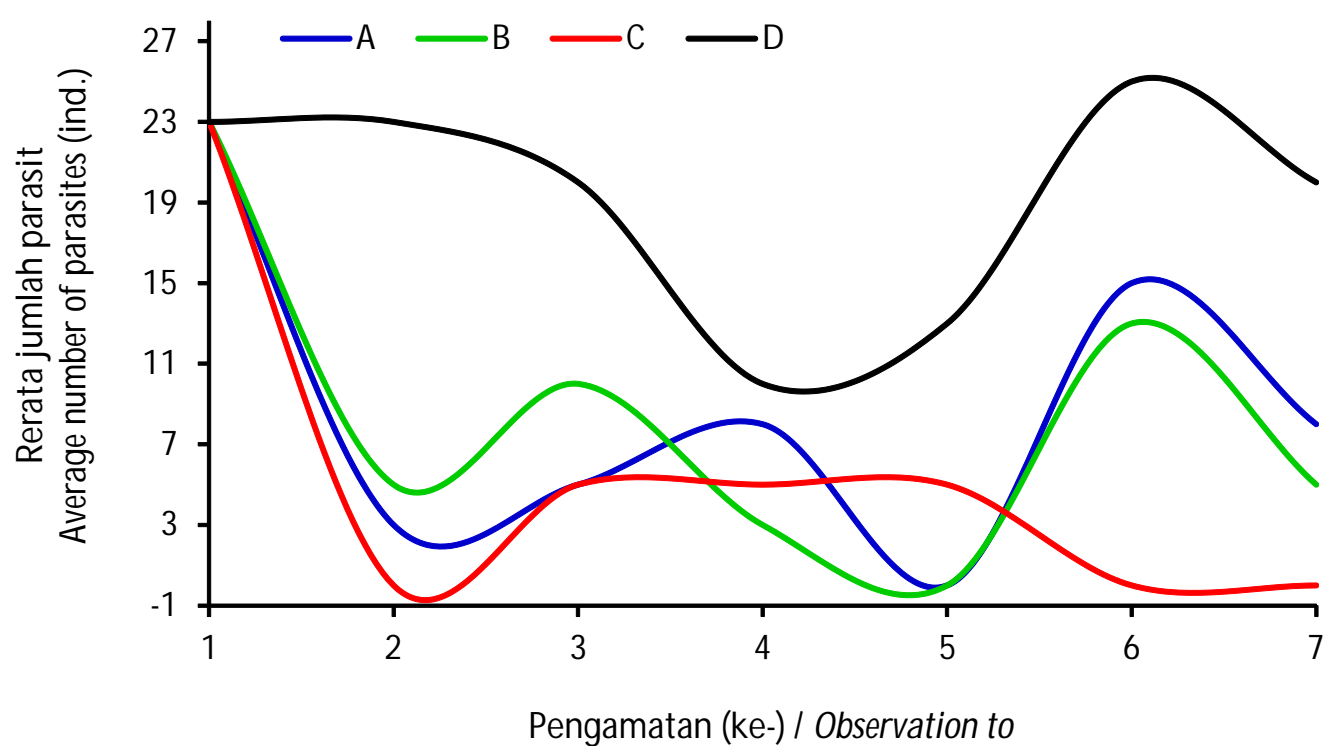

Gambar 1. Tingkat infestasi ektoparasit pada ikan lele selama pengujian dosis $\mathrm{H}_{2} \mathrm{O}_{2}$. Perlakuan $A=\mathrm{H}_{2} \mathrm{O}_{2}$ dosis $100 \mathrm{mg} / \mathrm{L}, \mathrm{B}=\mathrm{H}_{2} \mathrm{O}_{2}$ dosis $200 \mathrm{mg} / \mathrm{L}, \mathrm{C}=\mathrm{H}_{2} \mathrm{O}_{2}$ dosis $300 \mathrm{mg} / \mathrm{L}, \mathrm{D}=$ tanpa pemberian $\mathrm{H}_{2} \mathrm{O}_{2}$ (kontrol).

Figure 1. Ectoparasites infestation level on catfish during the application of $\mathrm{H}_{2} \mathrm{O}_{2}$. Treatment $A=\mathrm{H}_{2} \mathrm{O}_{2}$ dose of $100 \mathrm{mg} / \mathrm{L}, \mathrm{B}=\mathrm{H}_{2} \mathrm{O}_{2}$ dose of $200 \mathrm{mg} / \mathrm{L}, \mathrm{C}=\mathrm{H}_{2} \mathrm{O}_{2}$ dose of $300 \mathrm{mg} /$ $\mathrm{L}, \mathrm{D}=$ without $\mathrm{H}_{2} \mathrm{O}_{2}$ application (control).

membran dan masuk ke dalam tubuh parasit dewasa untuk kemudian bereaksi dengan $\mathrm{Fe}$ atau $\mathrm{Cu}$ membentuk radikal hidroksil $\left(\mathrm{OH}^{-}\right)$yang bersifat toksik dan mematikan bagi parasit. Lebih lanjut Schmidt \& Roberts (1977) menjelaskan mekanisme siklus hidup langsung parasit monogenea yang umumnya dengan satu inang dimulai dari telur, larva bersilia oncomiracidium, dan dewasa. Parasit Dactylogyrus vastator mampu mengeluarkan 4-10 telur setiap 24 jam sekali dan bahkan semakin meningkat jumlahnya seiring dengan bertambahnya temperatur. Menurut Olsen (1986), bahwa telur Dactylogyrus extensus berkembang selama lima hari pada temperatur $20^{\circ} \mathrm{C}$ dan menjadi parasit dewasa setelah 6-10 hari. Reed et al. (2012) juga menjelaskan bahwa parasit Gyrodactylus bersifat vivipar di mana telur berkembang dan menetas di dalam uterus, selanjutnya larva dilepaskan dan langsung menempel pada inang. Lebih lanjut Schmidt \& Roberts (1977) menyebutkan bahwa Gyrodactylus hanya membutuhkan waktu kurang lebih sehari untuk menjadi parasit dewasa setelah dilahirkan.

Pada akhir pengujian diperoleh rerata jumlah parasit terendah hingga tertinggi berturut-turut pada perlakuan dosis $300 \mathrm{mg} / \mathrm{L}, 200 \mathrm{mg} / \mathrm{L}, 100 \mathrm{mg} / \mathrm{L}$, dan kontrol. Semakin meningkatnya dosis ternyata berkorelasi pada semakin menurunnyatingkat infestasi ektoparasit pada seluruh kelompok perlakuan, meskipun secara umum pada akhir pengamatan perlakuan aplikasi $\mathrm{H}_{2} \mathrm{O}_{2}$ lebih efektif menekan jumlah parasit dibanding tanpa aplikasi $\mathrm{H}_{2} \mathrm{O}_{2}$ atau kontrol. Aplikasi $\mathrm{H}_{2} \mathrm{O}_{2}$ untuk pengobatan infeksi parasit pada ikan akan efektif dan aman jika digunakan dengan dosis yang tepat. Tidak ditemukannya ikan uji yang mati selama proses pengujian menunjukkan bahwa aplikasi $\mathrm{H}_{2} \mathrm{O}_{2}$ dengan dosis 100-300 mg/L aman digunakan dan tidak berbahaya bagi ikan lele. Sebagaimana pernyataan Schmidt et al. (2006) bahwa hidrogen peroksida merupakan salah satu bahan kimia yang telah memenuhi persyaratan sebagai desinfektan dalam kegiatan akuakultur. Hidrogen peroksida dengan dosis 250-500 mg/L telah digunakan untuk mengatasi infeksi jamur pada telur ikan, serta mengontrol bakteri dan parasit yang menginfeksi ikan budidaya. Hidrogen peroksida juga memiliki sifat alami mudah larut dan tidak berbahaya bagi ikan budidaya apabila diberikan dengan dosis yang tepat.

Pemberian $\mathrm{H}_{2} \mathrm{O}_{2}$ dengan dosis $300 \mathrm{mg} / \mathrm{L}$ menghasilkan tingkat infestasi terendah pada ketiga jenis ektoparasit (Trichodina sp., Dactylogyrus sp., dan Gyrodactylus sp.) (Gambar 2). Hasil tersebut menunjukkan bahwa aplikasi $\mathrm{H}_{2} \mathrm{O}_{2}$ dosis $300 \mathrm{mg} / \mathrm{L}$ lebih efektif menurunkan infestasi Trichodina sp., Dactylogyrus sp., dan Gyrodactylus sp. dibanding dosis $100 \mathrm{mg} / \mathrm{L}$ dan $200 \mathrm{mg} / \mathrm{L}$. Perlakuan kontrol tidak menunjukkan efektivitas terhadap ketiga jenis ektoparasit ditunjukkan dari jumlah parasit yang 

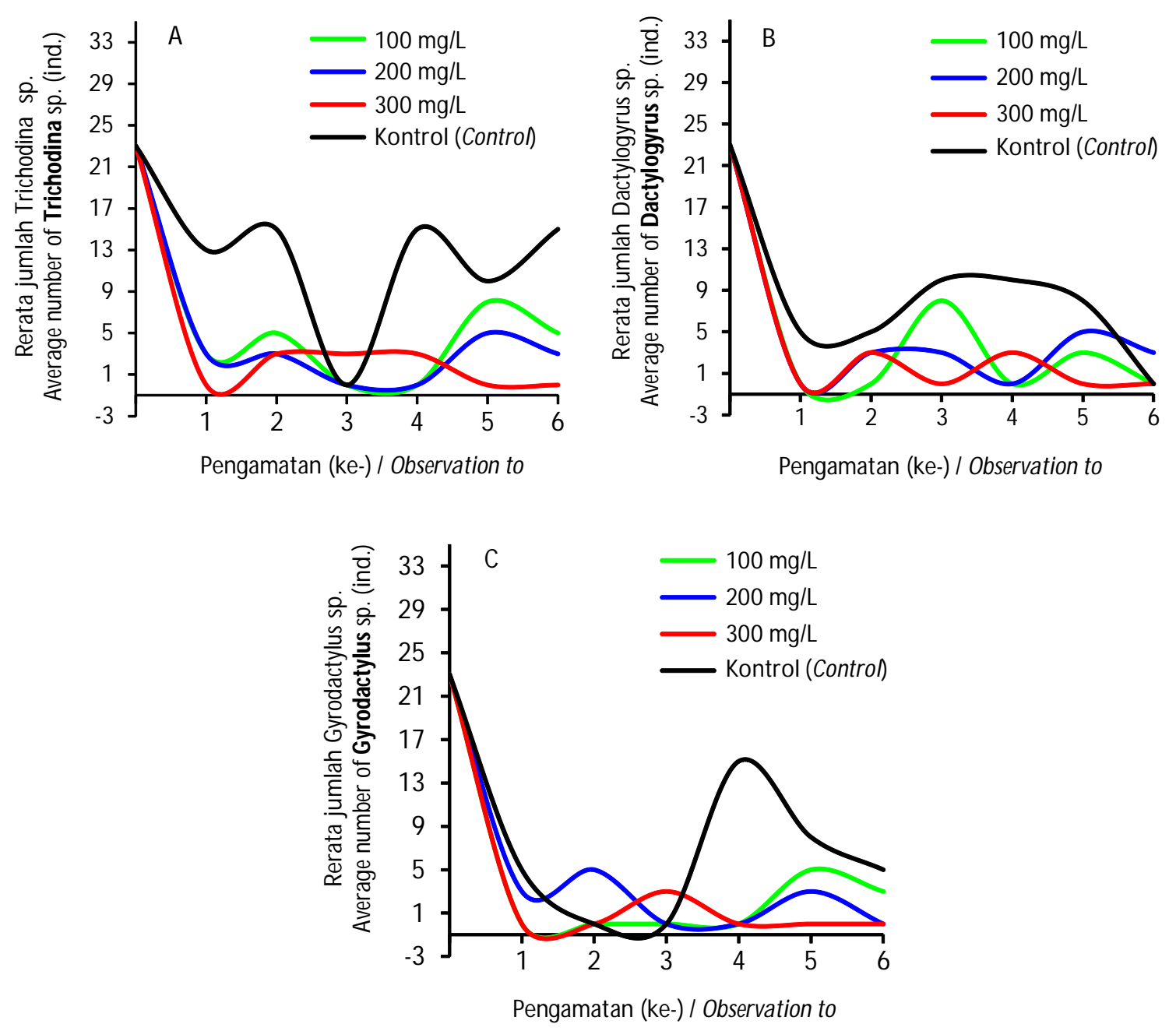

Gambar 2. Tingkat infestasi ektoparasit pada ikan lele dengan pengujian $\mathrm{H}_{2} \mathrm{O}_{2}$ dosis 100; 200; $300 \mathrm{mg} / \mathrm{L}$; dan kontrol. $(\mathrm{A})=$ parasit Trichodina sp., $(\mathrm{B})=$ parasit Dactylogyrus sp., dan $(C)=$ parasit Gyrodactylus sp.

Figure 2. Ectoparasites infestation level on catfish with $\mathrm{H}_{2} \mathrm{O}_{2}$ application doses $100 ; 200 ; 300 \mathrm{mg} / \mathrm{L}$; and control. $(A)=$ Trichodina $\mathrm{sp}_{.},(\mathrm{B})=$ Dactylogyrus sp., and $(\mathrm{C})=$ Gyrodactylus $\mathrm{sp}$.

menginfestasi pada akhir pengamatan. Infestasi Trichodina sp. memperlihatkan pola yang naik turun khususnya pada perlakuan kontrol (Gambar 2A). Pada pengamatan ke-3 jumlah parasit yang menginfestasi sempat menurun dan meningkat kembali hingga pengamatan ke-6. Mekanisme yang ditimbulkan akibat reaksi $\mathrm{H}_{2} \mathrm{O}_{2}$ di dalam tubuh parasit yang berbeda-beda waktunya menjadi penyebabnya. Kondisi tersebut mengakibatkan perbedaan jumlah parasit Trichodina sp. yang ditemukan pada ikan uji saat proses sampling. Perbedaan siklus hidup parasit, serta sampel ikan uji yang diperiksa turut memengaruhi jumlah parasit yang menginfestasi. Meskipun, secara umum berdasarkan rerata jumlah ektoparasit pada akhir pengamatan menunjukkan bahwa aplikasi $\mathrm{H}_{2} \mathrm{O}_{2}$ mampu menekan tingkat infestasi ketiga jenis ektoparasit dibandingkan tanpa aplikasi $\mathrm{H}_{2} \mathrm{O}_{2}$. Menurut Smith \& Schwarz (2009), siklus hidup Trichodina sp. sangatlah sederhana dengan satu inang dan proses infeksi terjadi melalui kontak langsung. Sementara proses reproduksi dilakukan dengan pembelahan biner yang terjadi pada kondisi temperatur optimum.

Hasil analisis statistik terhadap tingkat infestasi ektoparasit secara keseluruhan menunjukkan adanya perbedaan yang nyata $(\mathrm{P}<0,05)$ antara kelompok perlakuan aplikasi $\mathrm{H}_{2} \mathrm{O}_{2}$ dengan kontrol. Namun, tidak terdapat perbedaan yang nyata $(P>0,05)$ antar kelompok perlakuan $\mathrm{H}_{2} \mathrm{O}_{2}$ dosis $100 \mathrm{mg} / \mathrm{L}, 200 \mathrm{mg} / \mathrm{L}$, dan dosis $300 \mathrm{mg} / \mathrm{L}$ (Gambar 3). Menurut Schmidt et al. (2006), bahwa aplikasi hidrogen peroksida dengan konsentrasi berkisar $50 \mathrm{mg} / \mathrm{L}$ sampai dengan 1.000 


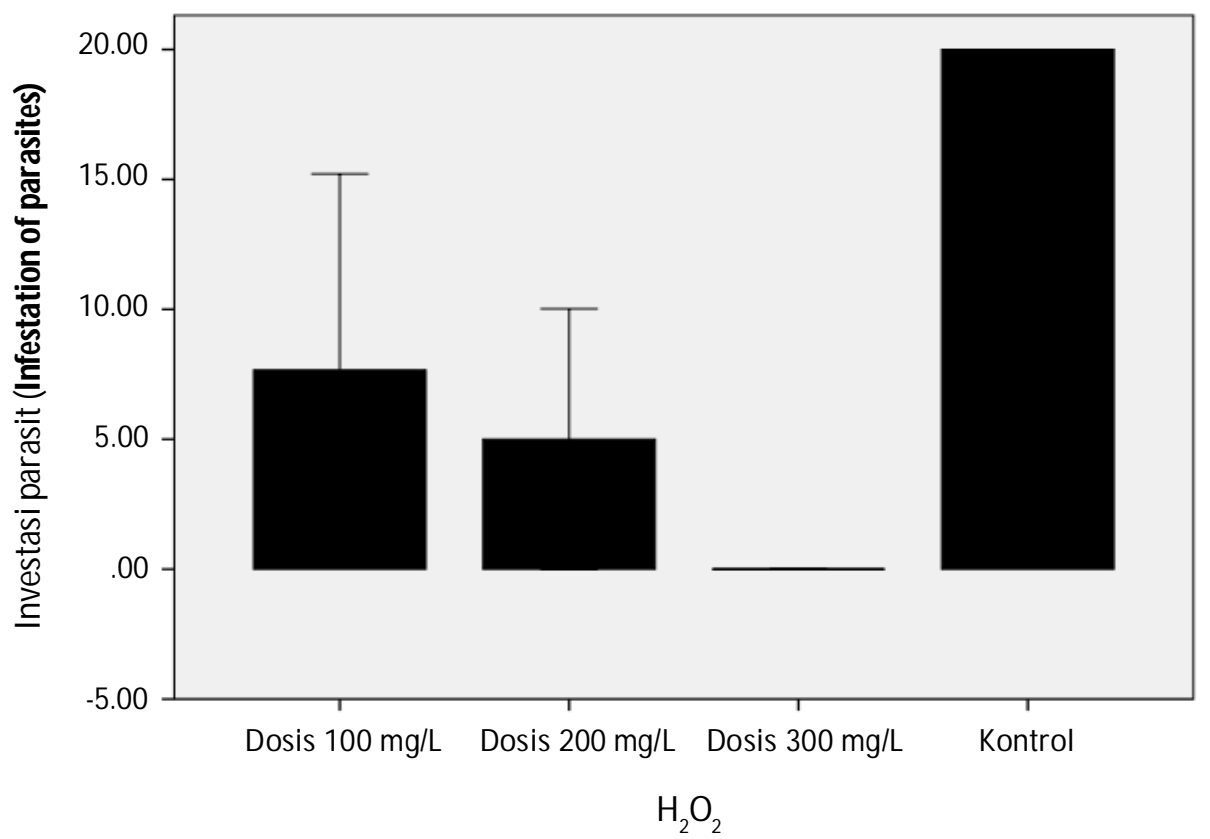

Gambar 3. Infestasi parasit pada akhir pengujian $\mathrm{H}_{2} \mathrm{O}_{2}$ dengan dosis $100 \mathrm{mg} / \mathrm{L}$, $200 \mathrm{mg} / \mathrm{L}, 300 \mathrm{mg} / \mathrm{L}$, dan kontrol.

Figure 3. Infestation of parasites at the end of the test with $\mathrm{H}_{2} \mathrm{O}_{2}$ application at a dose of $100 \mathrm{mg} / \mathrm{L}, 200 \mathrm{mg} / \mathrm{L}, 300 \mathrm{mg} / \mathrm{L}$, and control.

$\mathrm{mg} / \mathrm{L}$ telah banyak digunakan untuk mengatasi permasalahan penyakit pada fasilitas akuakultur, begitupula Athanassopoulou et al. (2009) menggunakan hidrogen peroksida untuk mengobati parasit jenis isopoda dan copepod, serta sebagai desinfektan dengan dosis $1.500 \mathrm{mg} / \mathrm{L}$ melalui perendaman selama 30 menit.

Infestasi ektoparasit menunjukkan efektivitas aplikasi $\mathrm{H}_{2} \mathrm{O}_{2}$ yang berbeda pada tiap jenis parasit (Gambar 4). Kelompok ikan yang direndam $\mathrm{H}_{2} \mathrm{O}_{2}$ dengan dosis $100 \mathrm{mg} / \mathrm{L}, 200 \mathrm{mg} / \mathrm{L}$, dan $300 \mathrm{mg} / \mathrm{L}$ memiliki efektivitas yang tidak berbeda nyata $(P>0,05)$ dalam menekan infestasi parasit Trichodina sp. Efektivitas seluruh pelakuan dosis berbeda nyata $(\mathrm{P}<0,05)$ terhadap kontrol, sedangkan efektivitas $\mathrm{H}_{2} \mathrm{O}_{2}$ terhadap infestasi parasit Dactylogyrus sp. pada dosis $100 \mathrm{mg} / \mathrm{L}, 300 \mathrm{mg} / \mathrm{L}$, dan kontrol tidak memperlihatkan perbedaan yang nyata $(P>0,05)$. Tingkat infestasi Dactylogyrus sp. pada perlakuan dosis $200 \mathrm{mg} / \mathrm{L}$ berbeda nyata $(P<0,05)$ dengan perlakuan lainnya, sementara terhadap infestasi parasit Gyrodacylus sp. tidak memperlihatkan perbedaan yang nyata $(P>0,05)$ antar perlakuan dosis $\mathrm{H}_{2} \mathrm{O}_{2}$. Perbedaan yang nyata $(P<0,05)$ hanya diperlihatkan antara kelompok pelakuan dosis $100 \mathrm{mg} / \mathrm{L}$ dengan kelompok tanpa pemberian $\mathrm{H}_{2} \mathrm{O}_{2}$ (kontrol). Hasil analisis statistik menunjukkan bahwa perlakuan pemberian $\mathrm{H}_{2} \mathrm{O}_{2}$ dengan dosis $300 \mathrm{mg} / \mathrm{L}$ memiliki efektivitas tertinggi dalam menekan tingkat infestasi ketiga jenis ektoparasit (Trichodina sp., Dactylogyrus sp., dan Gyrodactylus sp.) dibandingkan perlakuan lainnya yaitu $100 \mathrm{mg} / \mathrm{L}, 200 \mathrm{mg} / \mathrm{L}$, dan kontrol.

\section{Prevalensi Ektoparasit}

Semakin rendah prevalensi menunjukkan semakin efektifnya aplikasi bahan kimia dalam mengendalikan penyakit parasitik potensial. Nilai prevalensi ektoparasit yang diperoleh pada kelompok perlakuan aplikasi $\mathrm{H}_{2} \mathrm{O}_{2}$ pada akhir penelitian berturut-turut dari yang terkecil hingga terbesar yaitu perlakuan $300 \mathrm{mg} /$ L, $200 \mathrm{mg} / \mathrm{L}$, dan $100 \mathrm{mg} / \mathrm{L}$. Kisaran nilai prevalensi pada seluruh perlakuan pemberian $\mathrm{H}_{2} \mathrm{O}_{2}$ pada awal pengamatan sebesar $62,5 \% 100 \%$ dan turun pada akhir penelitian menjadi $0 \% 25 \%$ Prevalensi pada kontrol atau tanpa aplikasi $\mathrm{H}_{2} \mathrm{O}_{2}$ pada akhir penelitian berada pada kisaran 0\%100\% Prevalensi parasit Dactylogyrus sp. pada akhir pengujian dengan perlakuan pemberian $\mathrm{H}_{2} \mathrm{O}_{2}$ sebanyak $200 \mathrm{mg} / \mathrm{L}$ masih memperlihatkan nilai sebesar $25 \% \mathrm{Hal}$ tersebut menunjukkan bahwa pemberian $\mathrm{H}_{2} \mathrm{O}_{2}$ dengan dosis $200 \mathrm{mg} / \mathrm{L}$ tidak efektif menekan infestasi parasit Dactylogyrus sp. Prevalensi terendah diperoleh perlakuan aplikasi $\mathrm{H}_{2} \mathrm{O}_{2}$ dengan dosis $300 \mathrm{mg} / \mathrm{L}$ untuk jenis parasit Trichodina sp., Dactylogyrus sp., dan Gyrodactylus sp. (Tabel 1). Nilai prevalensi tersebut menunjukkan bahwa aplikasi $\mathrm{H}_{2} \mathrm{O}_{2}$ dosis $300 \mathrm{mg} / \mathrm{L}$ memiliki efektivitas terbaik dalam 

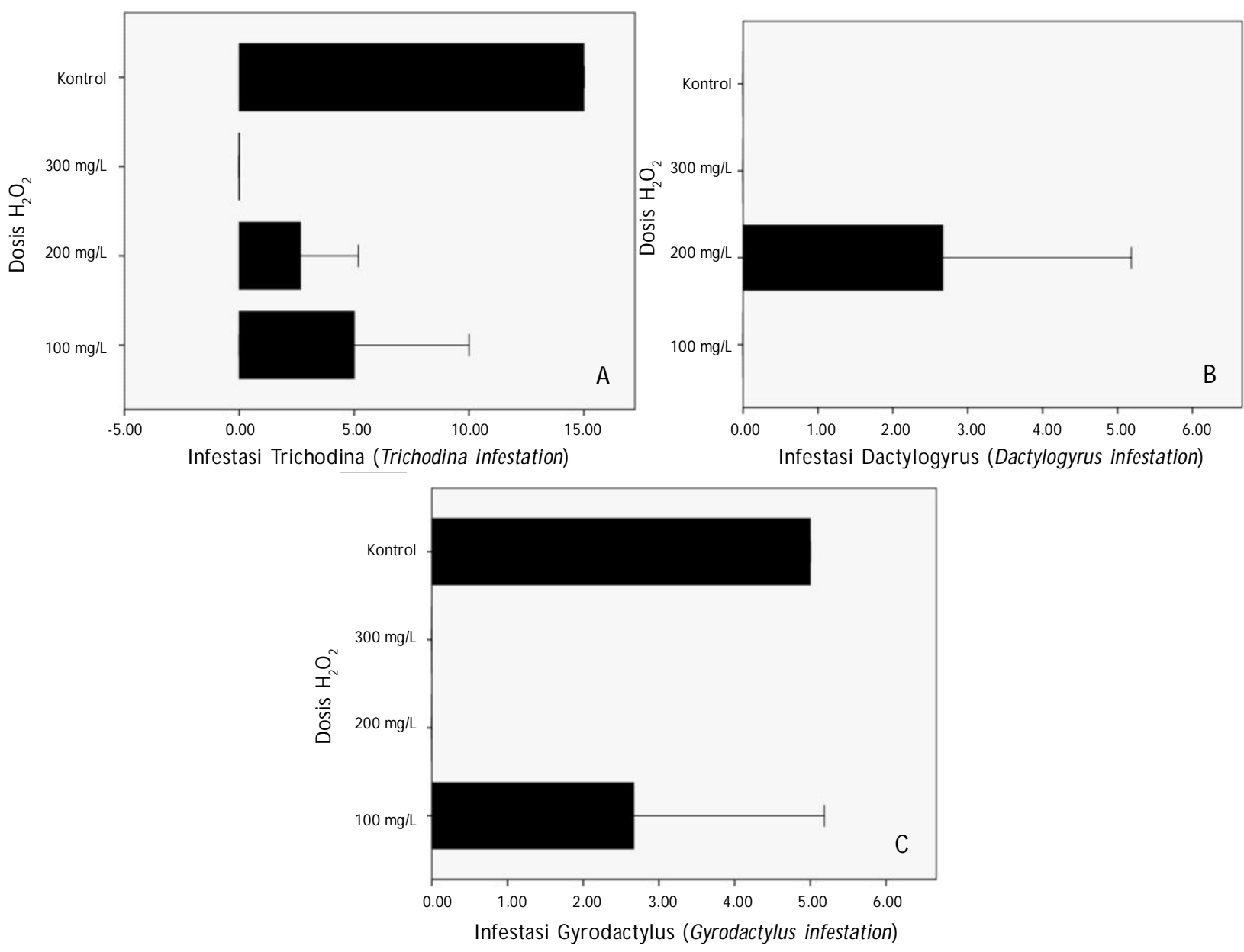

Gambar 4. Infestasi ektoparasit pada ikan lele dengan pengujian $\mathrm{H}_{2} \mathrm{O}_{2}$ dosis 100; 200; $300 \mathrm{mg} / \mathrm{L}$; dan kontrol. $(\mathrm{A})=$ Trichodina sp., $(\mathrm{B})=$ Dactylogyrus sp., dan $(\mathrm{C})=$ Gyrodactylus sp.

Figure 4. Ectoparasites infestation on catfish with $\mathrm{H}_{2} \mathrm{O}_{2}$ application doses $100 ; 200 ; 300 \mathrm{mg} / \mathrm{L}$; and control. $(A)=$ Trichodina sp., $(B)=$ Dactylogyrus sp., and $(C)=$ Gyrodactylus $s p$.

menekan prevalensi ektoparasit dibandingkan dengan aplikasi dosis $100 \mathrm{mg} / \mathrm{L}$ dan $200 \mathrm{mg} / \mathrm{L}$ maupun tanpa aplikasi. Hasil penelitian Schmidt et al. (2006) juga menunjukkan bahwa pemberian hidrogen peroksida dosis 250-500 mg/L selama 30-60 menit melalui perendaman mampu mengendalikan serangan ektoparasit. Lebih lanjut Rach et al. (2000) dalam penelitiannya juga memperlihatkan efektivitas penggunaan hidrogen peroksida dengan dosis 0-560 $\mathrm{mg} / \mathrm{L}$ pada juvenil rainbow trout, Oncorhynchus mykiss berhasil mengontrol parasit Ambiphrya dan Gyrodactylus yang menginfestasi.

Berdasarkan hasil pengujian diperoleh dosis efektif aplikasi $\mathrm{H}_{2} \mathrm{O}_{2}$ yang mampu menekan prevalensi ektoparasit pada ikan lele. Aplikasi $\mathrm{H}_{2} \mathrm{O}_{2}$ sebanyak 300 $\mathrm{mg} / \mathrm{L}$ merupakan dosis yang paling efektif dalam menurunkan prevalensi parasit Trichodina sp.,
Dactylogyrus sp., dan Gyrodactylus sp. dibandingkan dengan dosis $100 \mathrm{mg} / \mathrm{L}, 200 \mathrm{mg} / \mathrm{L}$, dan kontrol.

Hasil penelitian menunjukkan bahwa tingkat infestasi dan nilai prevalensi parasit Trichodina sp., Dactylogyrus sp., dan Gyrodactylus sp. pada akhir pengujian berhasil dikendalikan dengan aplikasi $\mathrm{H}_{2} \mathrm{O}_{2}$ dibandingkan tanpa aplikasi bahan tersebut. $\mathrm{Hal}^{2}$ tersebut mengindikasikan bahwa aplikasi $\mathrm{H}_{2} \mathrm{O}_{2}$ efektif mengendalikan infeksi parasit penyebab penyakit parasitik potensial seperti Trichodoniasis, Dactylogyriasis, dan Gyrodactyliasis pada ikan lele. Menurut Hirazawa et al. (2016), bahwa pengobatan menggunakan $75 \mathrm{mg} / \mathrm{L}$ hidrogen peroksida dengan perendaman selama 30 menit dapat menghilangkan penyakit yang disebabkan parasit cacing jenis monogenea yaitu Benedenia seriolae, Neobenedenia girellae, dan Zeuxapta japonica pada ikan aji-aji jalur 
Tabel 1. Prevalensi ikan uji terhadap parasit Trichodina sp., Dactylogyrus sp., dan Gyrodactylus sp. pada awal dan akhir pengujian dengan aplikasi hidrogen peroksida $\left(\mathrm{H}_{2} \mathrm{O}_{2}\right)$ pada tiap perlakuan.

Table 1. The prevalence of test fish against parasites Trichodina sp., Dactylogyrus sp., and Gyrodactylus sp. at the initial and end of the examination with the application of hydrogen peroxide $\left(\mathrm{H}_{2} \mathrm{O}_{2}\right)$ in each treatment.

\begin{tabular}{lccc}
\hline \multirow{2}{*}{$\begin{array}{c}\text { Jenis parasit yang menginfeksi } \\
\text { The type of infecting parasite }\end{array}$} & $\begin{array}{c}\text { Perlakuan dosis } \mathbf{H}_{\mathbf{2}} \mathbf{O}_{\mathbf{2}} \\
\text { Treatment of } \mathbf{H}_{\mathbf{2}} \mathbf{O}_{\mathbf{2}} \text { dose }\end{array}$ & \multicolumn{2}{c}{$\begin{array}{c}\text { Prevalensi } \\
\text { Prevalence (\% }\end{array}$} \\
\cline { 3 - 4 } & $100 \mathrm{mg} / \mathrm{L}$ & 100 & 50 \\
& Awal (Initial) & Akhir (End) \\
\hline \multirow{2}{*}{ Trichodina sp. } & $200 \mathrm{mg} / \mathrm{L}$ & 100 & 25 \\
& $300 \mathrm{mg} / \mathrm{L}$ & 100 & 0 \\
& Kontrol (Control) & 100 & 100 \\
\hline & $100 \mathrm{mg} / \mathrm{L}$ & 62,5 & 0 \\
Dactylogyrus sp. & $200 \mathrm{mg} / \mathrm{L}$ & 62,5 & 25 \\
& $300 \mathrm{mg} / \mathrm{L}$ & 62,5 & 0 \\
& Kontrol (Control) & 62,5 & 0 \\
\hline & $100 \mathrm{mg} / \mathrm{L}$ & 87,5 & 25 \\
Gyrodactylus sp. & $200 \mathrm{mg} / \mathrm{L}$ & 87,5 & 0 \\
& $300 \mathrm{mg} / \mathrm{L}$ & 87,5 & 0 \\
& Kontrol (Control) & 87,5 & 50 \\
\hline
\end{tabular}

kuning (Seriola dumerili). Lebih lanjut Barnes et al. (1998) juga mengaplikasikan hidrogen peroksida dengan dosis $1.000 \mathrm{mg} / \mathrm{L}$ untuk mengontrol pertumbuhan jamur Saprolegnia spp. pada telur ikan salmon. Sementara Hany (2014) menyatakan bahwa aplikasi hidrogen peroksida memiliki potensi sebagai pencegah penyakit khususnya pada ikan-ikan kecil yang lebih rentan terhadap infeksi berbagai macam penyakit, dikarenakan kemampuan dalam menurunkan nilai total bakteri. Begitupula pernyataan AvendanoHerrera et al. (2006) bahwa hidrogen peroksida dianjurkan sebagai desinfektan dalam budidaya ikan karena dapat mengontrol bakteri patogen Tenacibaculum maritimum pada ikan turbot (Scophthalmus maximus). Hal tersebut menunjukkan bahwa aplikasi hidrogen peroksida dapat digunakan pada aktivitas budidaya perikanan karena relatif aman bagi lingkungan dan dapat dijadikan sebagai desinfektan (Rasowo et al., 2007) maupun anti jamur (Barnes et al., 1998).

\section{KESIMPULAN}

Aplikasi hidrogen peroksida dengan dosis $300 \mathrm{mg} /$ L efektif menekan infeksi parasit Trichodina sp., Dactylogyrus sp., dan Gyrodactylus sp. pada ikan lele Clarias gariepinus.

\section{UCAPAN TERIMA KASIH}

Penelitian dibiayai DIPA Balai Penelitian dan Pengembangan Budidaya Air Tawar Bogor (BPPBAT) Tahun 2016. Penulis mengucapkan terima kasih kepada Kepala BPPBAT, Tim Peneliti Kesehatan Ikan, dan Sdr. Johan Afandi yang telah membantu selama proses penelitian.

\section{DAFTAR ACUAN}

Athanassopoulou, F., Pappas, I.S., \& Bitchava, K. (2009). An overview of the treatments for parasitic disease in Mediterranean aquaculture. Options M éditerranéennes, 86, 65-83.

Avendano-Herrera, R., Magarinos, B., Irgang, R., \& Toranzo, A.E. (2006). Use of hydrogen peroxide against the fish pathogen Tenacibaculum maritimumand its effect on infected turbot (Scophthalmus maximus). Aquaculture, 257, 104-110.

Barnes, M.E., Ewing, D.E., Cordes, R.J., \& Young, G.L. (1998). Observations on hydrogen peroxide control of Saprolegnia spp. during rainbow trout eggs incubation. The Progressive Fish-Culturist, 60, 6770.

Christison, K.W., Shinn, A.P., \& van As, J.S. (2005). Gyrodactylus thlapi n. sp. (Monogenea) from Pseudocrenilabrus philander philender (Weber) 
(Cichlidae) in the Okawango Delta, Botswana. Systematic Parasitology, 60, 165-173.

Direktorat Kesehatan Ikan dan Lingkungan [Dirkesling]. (2014). Buku saku pengendalian hama dan penyakit ikan. Jakarta: Direktorat Jenderal Perikanan Budidaya, Kementerian Kelautan dan Perikanan, hlm. 216.

Halliwel, B., \& Gutteridge, J.M. (2015). Free radicals in biology and medicine Fifth Edition. New York: Oxford University Press, $905 \mathrm{pp}$.

Hany, R.C.R. (2014). Efektivitas pemberian hidrogen peroksida terhadap kualitas media, kelangsungan hidup dan pertumbuhan benih ikan patin Pangasius sp. Skripsi. Institut Pertanian Bogor. Bogor, $26 \mathrm{hlm}$.

Hirazawa, N., Tsubone, S., \& Takano, R. (2016). Anthelmintic effects of $75 \mathrm{ppm}$ hydrogen peroxide treatment on themonogeneans Benedenia seriolae, Neobenedenia girellae, and Zeuxapta japonica infecting the skin and gills of greater amberjack Seriola dumerili. Aquaculture, 450, 244-249.

Hoffman, G.L. (1967). Parasites of North American Freshwater Fishes Los Angeles: University of California Press, 543 pp.

Kabata, Z. (1985). Parasites and diseases of fish cultured in the tropics. London Philadelphia: Taylor and Francis Ltd, $318 \mathrm{pp}$.

Kayis, S., Ozcelep, T., Capkin, E., \& Altinok, I. (2009). Protozoan and metazoan parasites of cultured fish in Turkey and their applied treatments. The Israeli Journal of Aquaculture-Bamidgeh, 61(2), 93-102.

Kudo, R.R. (1977). Protozoology. Illinois: Charles C Thomas Publisher, $1174 \mathrm{pp}$.

Lom, J., \& Dyková, I. (1992). Protozoan parasites of fishes. Amsterdam: Elsevier Science Publisher B.V., $315 \mathrm{pp}$.

Olsen, O.W. (1986). Animal parasites: Their life cycles and ecology. New York: Dover Publications, Inc., $562 \mathrm{pp}$.

Prikrylová, I., Blažek, R., \& Vanhove, M.P.M. (2012). An overview of the Gyrodactylus (Monogenea: Gyrodactylidae) species parasitizing African catfishes, and their morphological and molecular diversity. Parasitology Research, 110, 1185-1200.
Rach, J.J., Gaikowski, M.P., \& Ramsay, R.T. (2000). Efficacy of hydrogen peroxide to control parasitic infestations on hatchery-reared fish. Journal of Aquatic Animal Health, 12, 267-273.

Rasowo, J., Okoth, O.Y., \& Ngungi, C.C. (2007). Effects of formaldehyde, sodium chloride, potassium permanganate, and hydrogen peroxide on hatch rate of African catfish Clarias gariepinus eggs. Aquaculture, 269, 271-277.

Reed, P., Floyd, R.F., Klinger, R.E., \& Petty, D. (2012). Monogenean parasites of fish. University of Florida: IFAS Extension, $110 \mathrm{pp}$.

Rubio-Godoy, M., Paladini, G., Freeman, M.A., GarcíaVásquez, A., \& Shinn, A.P. (2012). Morphological and molecular characterisation of Gyrodactylus salmonis (Platyhelminthes, Monogenea) isolates collected in Mexico from rainbow trout (Oncorhynchus mykiss Walbaum). Veterinary Parasitology, 182, 289-300.

Schell, S.C. (1970). How to know the trematodes. lowa: W M.C. Brown Company Publishers, 355 pp.

Schmidt, G.D., \& Roberts, L.S. (1977). Foundations of parasitology. Saint Louis: The C.V. Mosby Company, $604 \mathrm{pp}$.

Schmidt, L.J., Gaikowski, M.P., \& Gingerich, W.H. (2006). Environmental assessment for the use of hydrogen peroxide in aquaculture for treating external fungal and bacterial diseases of cultured fish and fish eggs. La Crosse, Wisconsin: USGS Report, $180 \mathrm{pp}$.

Singkoh, M.F.O. (2012). Tingkat kesukaan parasit pada ikan mas (Cyprinus carpio) yang dipelihara dalam wadah jaring apung di Desa Eris, Kabupaten Minahasa, Provinsi Sulawesi Utara. Jurnal Bioslogos, 2(2), 63-69.

Smith, S., \& Schwarz, M. (2009). Dealing with trichodina and trichodina-like species. Commercial Fish and Shellfish Technology Fact Sheet: Virginia Cooperative Extension, 3 pp.

William, H., \& Jones, A. (1994). The parasitic worm of fish. London: Taylor \& Francis Ltd, 593 pp. 